\title{
Profil hematologi mencit (Mus musculus L.) strain Balb/c jantan akibat paparan asap rokok elektrik
}

\author{
Balb/c male mice (Mus musculus L.) hematogy profile \\ after electronic cigarette exposure
}

\author{
Eva Tyas Utami*, Ulfi Risqillah, Susantin Fajariah
}

Jurusan Biologi, Fakultas Matematika dan Ilmu Pengetahuan Alam,Universitas Jember, Jl. Kalimantan No. 37 Krajan Timur, Sumbersari, Kecamatan Sumbersari, Kabupaten Jember, Jawa Timur, Indonesia 68121

*Email: evatyas.utami@gmail.com

Diterima 29 Juli 2019

Disetujui 10 Nopember 2020

\section{INTISARI}

Rokok elektrik merupakan salah satu jenis rokok yang semakin banyak digemari. Hal ini dikarenakan kandungan nikotin dalam cairan rokok elektrik yang dapat diatur oleh penggunanya sehingga dianggap aman. Tujuan penelitian ini adalah untuk mengetahui pengaruh paparan asap rokok elektrik dengan volume cairan yang berbeda terhadap profil hematologi mencit (Mus musculus L) Strain Balb/c jantan. Pada penelitian ini digunakan Rancangan Acak Lengkap menggunakan 24 ekor mencit jantan dibagi menjadi empat kelompok yaitu kelompok satu merupakan kelompok kontrol (tidak dipapar asap rokok elektrik), kelompok dua,tiga, dan empat dipapar asap rokok elektrik dengan volume cairan sebanyak satu, dua, dan empat ml. Masing-masing kelompok terdiri atas enam ekor mencit sebagai ulangan. Dalam penelitian ini digunakan cairan rokok elektrik yang mengandung nikotin $6 \mathrm{mg} / \mathrm{ml}$. Pemaparan asap rokok elektrik dilakukan di dalam vaping box selama 28 hari. Pemaparan asap rokok dilakukan selama satu menit $/ \mathrm{mL}$ cairan dengan interval waktu pemberian selama 15 menit. Pengamatan profil hematologi meliputi kadar hemoglobin, jumlah eritrosit, jumlah leukosit dilakukan sebelum dan sehari setelah pemaparan asap rokok yang terakhir. Pengamatan profil hematologi dilakukan menggunakan hematologi analyzer. Hasil penelitian menunjukkan bahwa setelah paparan asap rokok elektrik dengan volume cairan yang berbeda terjadi peningkatan kadar hemoglobin dan jumlah eritrosit, penurunan jumlah leukosit dan limfosit serta tidak terjadi perubahan jumlah granulosit dan MID (midrange limfosit dan neutrophil). Kesimpulan penelitian ini, paparan asap rokok elektrik dengan volume cairan $1 \mathrm{~mL}$ berpengaruh terhadap profil hematologi mencit dengan meningkatkan kadar $\mathrm{Hb}$, menurunkan leukosit dan limfosit. Paparan dengan volume $4 \mathrm{~mL}$ meningkatkan rata-rata jumlah eritrosit. Perlakuan dengan volume cairan yang berbeda tidak berpengaruh terhadap rata-rata jumlah granulosit dan MID.

Kata kunci: Rokok elektrik, kadar hemoglobin, eritrosit, leukosit

\begin{abstract}
E-cigarettes are a type of cigarette that is becoming increasingly popular. This is because the nicotine content in e-cigarette liquid can be regulated by the user so that it is considered safe. The purpose of this study was to determine the effect of exposure to e-cigarette smoke with different fluid volumes on the hematological profile of male mice (Mus musculus Balb/c). This experiment used a completely randomized design using 24 male mice divided into four groups, namely group $1^{\text {st }}$ was a kontrol group (not exposed to e-cigarette smoke), groups $2^{\text {nd }}, 3^{\text {th }}$, and $4^{\text {th }}$ were exposed to e-cigarette smoke with a volume of 1,2 , and 4
\end{abstract}


$\mathrm{mL}$. Each group consisted of six mice as replicates. This experiment used e-cigarette liquid containing nicotine $6 \mathrm{mg} / \mathrm{ml}$. Exposure to E-cigarette smoke was carried out in a vaping box for 28 days. Cigarette smoke exposure was carried out for one minute/mL of liquid with an interval of 15 minutes. Observation of the haematological profile included hemoglobin levels, erythrocyte counts, leukocyte counts carried out before and the day after the last exposure to cigarette smoke. Hematology profile observations were carried out using a hematology analyzer. The results showed that after exposure to e-cigarette smoke with different fluid volumes there was an increase in hemoglobin and erythrocyte counts, a decrease in the number of leukocytes and lymphocytes and no change in the number of granulocytes and MID (midrange lymphocytes and neutrophils). The conclusion of this study, exposure to e-cigarette smoke with a fluid volume of $1 \mathrm{~mL}$ affects the hematological profile of mice by increasing $\mathrm{Hb}$ levels, reducing leukocytes and lymphocytes. Exposure to a volume of $4 \mathrm{~mL}$ increased the mean erythrocyte count. Treatment with different fluid volumes had no effect on the average number of granulocytes and MID.

\section{Keywords: Electronic cigarette, hemoglobin level, erytrocytes, leukocytes}

\section{PENDAHULUAN}

Penggunaan rokok elektrik di Indonesia pada tahun 2018 mencapai 2,1 juta orang dan terus terjadi peningkatan. Rokok elektrik dianggap sebagai rokok yang aman dan tidak berbahaya bagi kesehatan karena tidak mengalami proses pembakaran dan pengguan dapat menagtur kadar nikotin yang diinginkan. Namun, penggunaan rokok elektrik ternyata dapat berdampak buruk pada kesehatan terutama pada bagian sistem pernapasan dan sistem kardiovaskular (Campagna et al., 2016; McConnel et al., 2016; Vardavas et al., 2012). Hasil penelitian Shi et al. (2019) menunjukkan efek penggunaan rokok elektrik dengan kadar nikotin $24 \mathrm{mg} / \mathrm{ml}$ selama 2 minggu dapat meningkatkan angiogenesis jaringan jantung dan menurunkan berat badan pada mencit. Diketahui bahwa rokok elektrik juga berpengaruh terhadap darah. Paparan asap rokok elektrik dengan kadar nikotin 6, 12, dan 18 mg/ml selama 3 minggu dapat meningkatkan rata-rata jumlah leukosit darah Rana pipiens (Jude et al., 2017).

Pemeriksaan hematologi adalah pemeriksaan untuk mengetahui keadaan darah dan komponenkomponennya (Handayani et al., 2013) antara lain meliputi kadar hemoglobin, jumlah eritrosit dan jumlah leukosit dan jenis leukosit dalam darah. Pemeriksaan hematologi dianggap sangat penting karena berkaitan dengan keadaan atau kondisi pasien secara menyeluruh yang bertujuan untuk mendeteksi adanya infeksi yang disebabkan oleh parasit, virus, bakteri dan berbagai senyawa kimia yang berbahaya bagi tubuh (Rahardjo et al., 2011 dan Widyastuti, 2013). Berdasarkan penelitian Wibowo et al., 2017 kadar hemoglobin dapat menjadi salah satu indikator pengaruh asap rokok terhadap kesehatan. Pemeriksaan leukosit darah dapat mendeteksi adanya kelainan darah yang disebabkan oleh zat toksik antara lain oleh adanya paparan asap rokok (Nursidika et al., 2019).

Menurut Garcia et al. (2016) paparan asap dua batang rokok konvensional setiap hari dapat meningkatkan jumlah produksi makrofag dan neutrofil pada mencit. Penelitian lain juga menyebutkan bahwa penggunaan rokok elektrik setiap hari dengan dosis $21 \mathrm{mg}$ nikotin selama 6 bulan dapat meningkatkan jumlah leukosit pada manusia (Edmonds et al., 2020). Peningkatan jumlah leukosit ini merupakan bentuk proteksi tubuh terhadap zat toksik yang masuk. Selain itu, penelitian Makawekes et al. (2016) dan Wibowo et al. (2017) menyebutkan bahwa kadar hemoglobin perokok lebih tinggi dibanding dengan yang bukan perokok. Seiring meningkatnya penggunaan rokok elektrik di masyarakat serta mempertimbangkan dampak yang diakibatkan maka perlu dilakukan penelitian mengenai profil hematologi mencit akibat paparan asap rokok elektrik menggunakan volume cairan yang berbeda.

\section{MATERI DAN METODE}

Tempat dan waktu penelitian 
Penelitian dilaksanakan pada bulan September sampai dengan Desember 2019 di Laboratorium Zoologi Jurusan Biologi, Fakultas Matematika dan Ilmu Pengetahuan Alam, Universitas Jember dan Laboratorium Prosenda Jember.

\section{Bahan dan alat}

Alat yang digunakan meliputi kandang mencit berupa bak plastik dengan tutup ram kawat, botol minum mencit, wadah makan mencit, jarum gavage, tusuk gigi, papan bedah, timbangan analitik (Ohaus), kasa, OptiLab, scalpel, mikroskop Nikon, Vaping box kaca berukuran $40 \times 30 \times 25 \mathrm{~cm}^{3}$, alat penghasil asap rokok elektrik (vapor), aerator, micro hematocrite tubes non heparin, dan hematology analyzer dymindh-DH. Alat yang digunakan untuk pemaparan asap rokok elektrik pada mencit dapat dilihat pada Gambar 1.
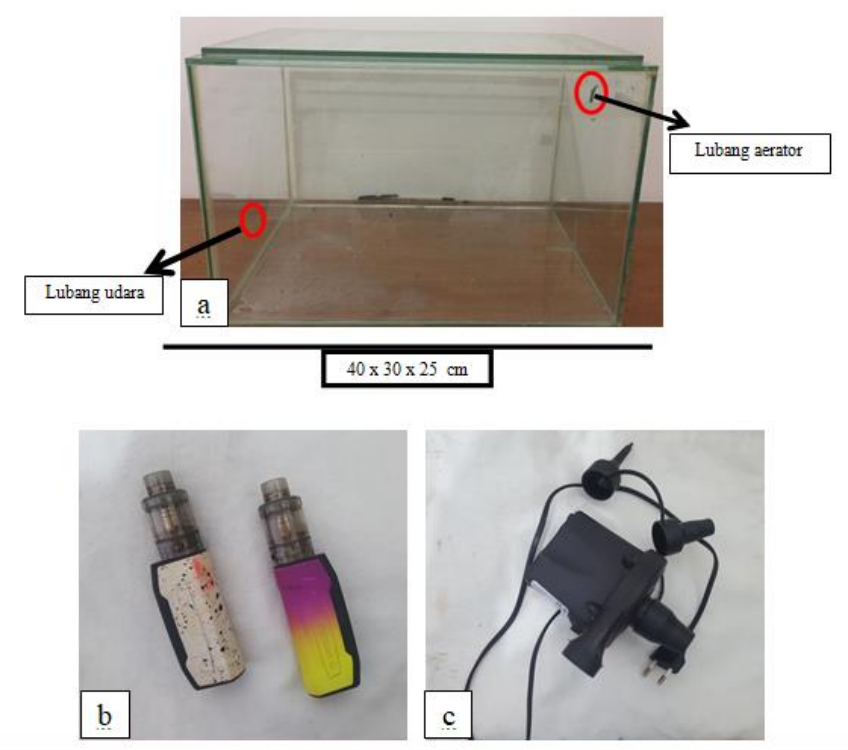

Gambar 1. Alat-alat yang digunakan untuk proses pemaparan asap rokok elektrik pada mencit (a) vaping box; (b) vapor; (c) aerator

Bahan penelitian meliputi hewan uji Mus musculus L. jantan Strain Balb/c berumur enam sampai delapan minggu diperoleh dari Pusat Veterinaria Farma (Pusvetma) Surabaya dengan berat 25-30 g, pakan pelet broiler (BR1 Plus), akuades, cairan rokok elektrik yang mengandung nikotin enam $\mathrm{mg} / \mathrm{ml}$ dengan aroma strawberry oat meal, gelas objek, gelas penutup, metanol, pewarna Giemsa, EDTA.

\section{Metode}

Penelitian ini merupakan jenis penelitian eksperimental menggunakan Rancangan Acak Lengkap (RAL) menggunakan 24 ekor mencit jantan yang dibagi menjadi empat kelompok masing-masing terdiri atas enam ekor mencit sebagai ulangan. Kelompok satu merupakan kelompok kontrol tanpa paparan asap rokok elektrik. Kelompok dua dipapar asap rokok elektrik dengan volume cairan sebanyak $1 \mathrm{ml}$. Kelompok tiga dipapar asap rokok elektrik dengan volume cairan sebanyak $2 \mathrm{ml}$. Kelompok empat dipapar asap rokok elektrik dengan volume cairan sebanyak $4 \mathrm{ml}$. Paparan asap rokok elektrik dilakukan selama 28 hari di dalam vaping box yang diberi lubang udara (aerator) dan lubang untuk paparan asap rokok elektrik (vapor) seperti tampak pada Gambar 1. Paparan asap rokok dilakukan selam 1 menit $/ \mathrm{mL}$ dan diberi interval waktu selam 15 menit sebelum dilakukan paparan asap rokok elektrik selanjutnya. Pengambilan darah awal diambil sebelum paparan asap rokok dilakukan dan sehari setelah paparan asap rokok yang terakhir. Darah diambil melalui orbital mata dan ekor. Darah yang diambil melalui orbital mata sebanyak 100-300 $\mu$ l dimasukkan dalam tabung yang mengandung $\mathrm{K}_{3}$ EDTA.selanjutnya dilakukan pemeriksaan hematologi menggunakan hematologi analyzer sedangkan darah yang diambil melalui ekor dibuat preparat apus darah untuk pengamatan jenis-jenis leukosit.

\section{Pembuatan preparat apus darah}

Apusan darah dilakukan dengan cara mengambil darah dari ekor mencit dan kemudian diteteskan pada objek gelas. Tetesan darah dibuat ulasan setipis mungkin pada objek gelas, dilanjutkan fiksasi dengan metanol selama tiga sampai lima menit. Pewarnaan Giemsa dilakukan selama 15 menit pada apusan darah yang telah difiksasi dengan metanol. Preparat yang telah diwarnai kemudian dicuci menggunakan air mengalir kemudian dikeringanginkan (Ardina dan Rosalinda, 2018). Preparat apus untuk melihat jenis-jenis sel darah putih yakni neutrofil, basofil, eusinofil, monosit dan limfosit. 


\section{Pemeriksaan hematologi}

Pemeriksaan hematologi darah pada penelitian ini dilakukan dengan cara otomatis menggunakan alat hematologi analyzer. Pemeriksaan hematologi dilakukan sebelum perlakuan dan sehari setelah perlakuan pemaparasn asap rokok elektik yang terakhir. Dilakukan pengambilan darah melalui pembuluh darah orbital (mata) sebanyak 100-300 $\mu$ l. Selanjutnya darah dimasukkan ke dalam tabung yang mengandung K3EDTA. Darah yang diperoleh tersebut selanjutnya diuji di Laboratorium Prosenda Jember menggunakan hematology analyzer. Data yang diukur berupa kadar hemoglobin, jumlah sel darah merah, jumlah dan jenis sel darah putih meliputi leukosit, limfosit, granulosit dan MID (mid range limfosit dan neutrophil)

\section{Analisis data}

Data hasil pengamatan diolah dengan menggunakan uji Paired Sample Test untuk mengetahui profil hematologi sebelum dan pasca paparan asap rokok elektrik, dan uji ANOVA menggunakan SPSS System 16.0 dengan dengan taraf kepercayaan $95 \%$ atau $\alpha=0,05$ untuk melihat pengaruh paparan asap rokok elektrik terhadap profil hematologi. Selanjutnya, untuk mengetahui beda nyata antar kelompok dilakukan analisis uji Duncan Multiple Range Test (DMRT) (Steel and Torrie, 1993).

\section{HASIL}

Hasil penelitian menunjukkan bahwa paparan asap rokok elektrik selama 4 minggu berpengaruh signifikan $(\mathrm{p}<0,05)$ terhadap kadar hemoglobin, jumlah eritrosit, jumlah leukosit dan jumlah limfosit. Kadar hemoglobin dan rata-rata jumlah eritrosit sebelum dan setelah paparan asap rokok dapat dilihat pada Tabel 1. Berdasarkan uji paired T-test diperoleh nilai sig. $\mathrm{p} \leq 0,05$ pada rata-rata kadar hemoglobin untuk semua kelompok perlakuan dan untuk rata-rata jumlah eritrosit diperoleh nilai sig. $\mathrm{p} \leq 0,05$ pada kelompok perlakuan paparan asap rokok elektrik dengan volume cairan $4 \mathrm{ml}$. Berdasarkan hasil tersebut tampak bahwa kadar hemoglobin setelah paparan asap rokok elektrik berbeda sangat signifikan dibandingkan sebelum paparan asap rokok elektrik pada semua kelompok perlakuan sedangkan rata-rata jumlah eritrosit setelah paparan asap rokok elektrik hanya pada kelompok paparan asap rokok elektrik dengan volume cairan $4 \mathrm{ml}$ yang menunjukkan perbedaan secara signifikan dibandingkan sebelum paparan.

Tabel 1. Rata-rata kadar hemoglobin dan eritrosit darah mencit sebelum dan sesudah paparan asap rokok elektrik

\begin{tabular}{|c|c|c|c|c|}
\hline \multirow[b]{2}{*}{$\begin{array}{l}\text { Kelompok } \\
\text { Perlakuan }\end{array}$} & \multicolumn{2}{|c|}{ Kadar Hemoglobin (g/dL) } & \multicolumn{2}{|c|}{ Eritrosit $\left(10^{6} / \mathrm{mm}^{3}\right)$} \\
\hline & $\begin{array}{l}\text { Sebelum } \\
(\bar{x} \pm \mathbf{s d})\end{array}$ & $\begin{array}{c}\text { Sesudah } \\
(\bar{x} \pm \mathbf{s d})\end{array}$ & $\begin{array}{l}\text { Sebelum } \\
(\bar{x} \pm \mathbf{s d})\end{array}$ & $\begin{array}{l}\text { Sesudah } \\
(\bar{x} \pm \mathbf{s d})\end{array}$ \\
\hline Kontrol & $15,08 \pm 0,71$ & $15,41 \pm 0,66^{\mathrm{a}}$ & $8,55 \pm 0,84$ & $8,18 \pm 0,77^{a}$ \\
\hline $1 \mathrm{ml}$ & $14,45 \pm 0,34$ & $16,01 * * \pm 0,4^{\mathrm{b}}$ & $8,37 \pm 1,32$ & $9,08 \pm 1,06^{\mathrm{ab}}$ \\
\hline $2 \mathrm{ml}$ & $14,43 \pm 0,48$ & $16,01^{* *} \pm 0,23^{\mathrm{b}}$ & $9,07 \pm 0,88$ & $9,15 \pm 0,66^{\mathrm{ab}}$ \\
\hline $4 \mathrm{ml}$ & $14,43 \pm 0,48$ & $16,28^{* *} \pm 0,4^{b}$ & $7,76 \pm 1,18$ & $9,56^{*} \pm 0,55^{\mathrm{b}}$ \\
\hline
\end{tabular}

Uji DMRT menunjukkan bahwa kadar $\mathrm{Hb}$ pada perlakuan sesudah paparan asap rokok elektrik dengan volume cairan $1 \mathrm{ml}$ menunjukkan hasil yang berbeda nyata dengan kontrol namun tidak berbeda nyata antar perlakuan. Demikian pula rata-rata jumlah eritrosit setelah paparan asap rokok elektrik menggunakan volume 1, 2, dan 4 $\mathrm{mL}$ menunjukan tidak beda nyata, namun rata- rata jumlah eritrosit pada perlakuan volume cairan $4 \mathrm{ml}$ menunjukkan beda nyata dengan kontrol.

Rata-rata jumlah leukosit sebelum dan sesudah perlakuan asap rokok dapat dilihat pada Tabel 2. Hasil uji paired T-test untuk rata-rata jumlah leukosit diperoleh nilai sig. $\mathrm{p} \leq 0,05$ pada semua 
kelompok perlakuan. Berdasarkan hasil tersebut tampak bahwa jumlah leukosit setelah paparan asap rokok elektrik berbeda signifikan untuk kelompok perlakuan paparan asap rokok elektrik dengan volume cairan $1 \mathrm{ml}$ dan $2 \mathrm{ml}$ dan berbeda sangat signifikan untuk kelompok perlakuan perlakuan paparan asap rokok elektrik dengan volume cairan $4 \mathrm{ml}$ dibandingkan sebelum paparan.

Tabel 2. Rata-rata jumlah leukosit dalam darah mencit sebelum dan sesudah paparan asap rokok elektrik

\begin{tabular}{lcc}
\hline \multirow{2}{*}{$\begin{array}{c}\text { Kelompok } \\
\text { Perlakuan }\end{array}$} & \multicolumn{2}{c}{ Rata-rata jumlah leukosit $\left(10^{3} / \mu 1\right)$} \\
\cline { 2 - 3 } Kontrol & Sebelum $(\bar{x} \pm$ SD $)$ & Sesudah $(\bar{x} \pm$ SD $)$ \\
$1 \mathrm{ml}$ & $6,30 \pm 1,84$ & $6,61 \pm 2,4^{\mathrm{b}}$ \\
$2 \mathrm{ml}$ & $5,61 \pm 1,82$ & $3,29^{*} \pm 1,32^{\mathrm{a}}$ \\
$4 \mathrm{ml}$ & $8,02 \pm 2.35$ & $3,20^{*} \pm 1,12^{\mathrm{a}}$ \\
\hline
\end{tabular}

Hasil uji DMRT menunjukkan bahwa paparan asap rokok elektrik dengan volume cairan $1 \mathrm{ml}$ berbeda signifikan dengan kontrol, namun tidak berbeda secara signifikan antar kelompok perlakuan. Rata-rata jumlah leukosit setelah pemaparan asap rokok elektrik dengan volume yang berbeda menunjukkan penurunan dibandingkan kontrol.

Rata-rata jumlah limfosit sebelum dan sesudah perlakuan dapat dilihat pada Tabel 3 . Berdasarkan tabel diperoleh nilai sig. $\mathrm{p} \leq 0,05$ untuk semua kelompok perlakuan. Berdasarkan hasil tersebut menunjukkan bahwa jumlah limfosit setelah paparan asap rokok elektrik berbeda signifikan dibandingkan sebelum paparan asap rokok elektrik pada semua kelompok perlakuan. Hasil uji DMRT menunjukkan bahwa paparan asap rokok elektrik dengan volume cairan $1 \mathrm{ml}$ berbeda signifikan dengan kontrol, namun tidak berbeda secara signifikan antar kelompok perlakuan. Pemaparan asap rokok elektrik dengan volume yang berbeda menunjukkan penurunan rata-rata jumlah limfosit dibandingkan kontrol.

Tabel 3. Rata-rata jumlah limfosit dalam darah mencit sebelum dan sesudah paparan asap rokok elektrik

\begin{tabular}{ccc}
\hline Kelompok & \multicolumn{2}{c}{ Rata-rata jumlah limfosit $\left(10^{3} / \mu 1\right)$} \\
\cline { 2 - 3 } Perlakuan & Sebelum $(\bar{x} \pm$ SD $)$ & Sesudah $(\bar{x} \pm$ SD $)$ \\
\hline Kontrol & $5,85 \pm 1,87$ & $5,92 \pm 2,16^{\mathrm{b}}$ \\
$1 \mathrm{ml}$ & $6,22 \pm 1,72$ & $2,82^{*} \pm 1,25^{\mathrm{a}}$ \\
$2 \mathrm{ml}$ & $5,35 \pm 1,66$ & $2,79^{*} \pm 1,09^{\mathrm{a}}$ \\
$4 \mathrm{ml}$ & $7,12 \pm 2,25$ & $2,96^{*} \pm 1,35^{\mathrm{a}}$ \\
\hline
\end{tabular}

Rata-rata jumlah granulosit dan MID sebelum dan setelah perlakuan dapat dilihat pada Tabel 4. Granulosit terdiri atas neutrofil sedangkan MID merupakan campuran dari monosit, eosinofil dan basofil. Berdasarkan tabel rata-rata jumlah granulosit dan MID diperoleh nilai sig. $\mathrm{p} \geq 0,05$ untuk semua kelompok perlakuan. Berdasarkan uji Anova tampak bahwa rata-rata jumlah granulosit dan MID setelah paparan asap rokok elektrik tidak berbeda nyata antara kelompok kontrol dan kelompok perlakuan.

Tabel 4 Rata-rata jumlah granulosit dan MID dalam darah mencit sebelum dan sesudah paparan asap rokok elektrik

\begin{tabular}{|c|c|c|c|c|}
\hline \multirow[b]{2}{*}{$\begin{array}{l}\text { Kelompok } \\
\text { Perlakuan }\end{array}$} & \multicolumn{2}{|c|}{ Granulosit $\left(10^{3} / \mu 1\right)$} & \multicolumn{2}{|c|}{$\operatorname{MID}\left(10^{3} / \mu \mathrm{l}\right)$} \\
\hline & $\begin{array}{l}\text { Sebelum } \\
(\bar{x} \pm \mathbf{S D})\end{array}$ & $\begin{array}{l}\text { Sesudah } \\
(\bar{x} \pm \mathbf{S D})\end{array}$ & $\begin{array}{l}\text { Sebelum } \\
(\bar{x} \pm \mathbf{S D})\end{array}$ & $\begin{array}{l}\text { Sesudah } \\
(\bar{x} \pm \mathbf{S D})\end{array}$ \\
\hline kontrol & $0,77 \pm 0,185$ & $0,60 \pm 0,05$ & $0,09 \pm 0,04$ & $0,07 \pm 0,06$ \\
\hline $1 \mathrm{ml}$ & $0,30 \pm 0,09$ & $0,41 \pm 0,14$ & $0,07 \pm 0,02$ & $0,05 \pm 0,02$ \\
\hline $2 \mathrm{ml}$ & $0,41 \pm 0,18$ & $0,33 \pm 0,05$ & $0,05 \pm 0,04$ & $0,07 \pm 0,06$ \\
\hline $4 \mathrm{ml}$ & $0,77 \pm 0,43$ & $0,47 \pm 0,23$ & $0,12 \pm 0,07$ & $0,07 \pm 0,05$ \\
\hline
\end{tabular}


Dari pembuatan preparat apus darah dapat dilihat jenis-jenis sel darah putih meliuti: leukosit granulosit (neutrophil, eosinophil dan basophil) dan leukosit agranulosit (limfosit dan monosit). Neutrofil merupakan jenis leukosit yang memiliki inti berjumlah tiga samapai lima lobus dengan granula berwarna merah (Mescher, 2017). Neutrofil berperan sebagai pertahanan garis pertama (first line of defense). Bersama dengan makrofag, neturofil memiliki kemampuan fagositosis terhadap organisme patogen dan sel debris (Junqueira and Carneiro 2005). Eosinofil memiliki inti berjumlah dua dengan granula berwarna merah atau pink gelap sedangkan basofil memiliki inti berjumlah dua atau berbentuk S (Frandson, 1992). Eosinofil memiliki kemampuan yang sama dengan basofil atau sel mast sebagai mediator peradangan terhadap reaksi alergi (Weiss and Wardrop, 2010). Gambar neutrofil, eosinophil, basofil hasil apusan darah dapat dilihat pada Gambar 2.

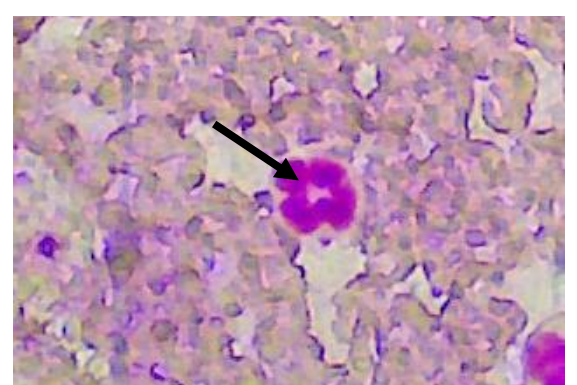

(a)

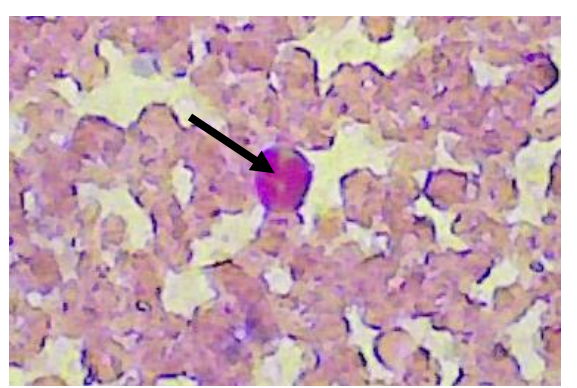

(b)

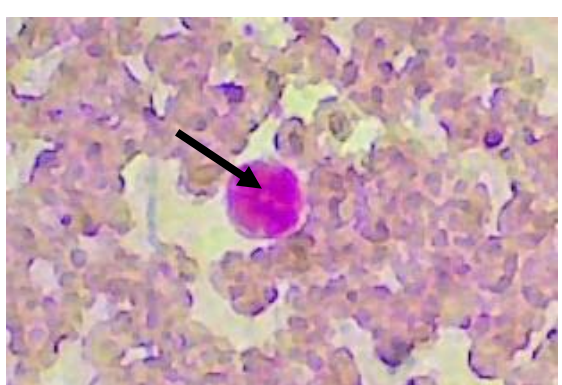

(c)

Gambar 2. Morfologi granulosit (a) neutrofil (b) basofil dan (c) eosinofil. Tanda panah menunjukkan jenis granulosit menggunakan perbesaran 400x

Monosit memiliki inti berlekuk atau bentuk $\mathrm{C}$ dan sitoplasma tidak memiliki granula (Mescher, 2017). Monosit merupakan jenis leukosit yang dapat berdiferensiasi menjadi makrofag. Monosit berfungsi dalam membersihkan sel debril yang dihasilkan dari proses peradangan, memproses antigen yang menempel pada sel limfosit sehingga mudah dicerna dan menghancurkan zat asing yang masuk ke dalam tubuh (Colville and
Bassert, 2008). Limfosit memiliki inti agak bulat dan sitoplasma tidak memiliki granula (Mescher, 2017). Limfosit merupakan satu-satunya jenis leukosit yang tidak memiliki kemampuan fagositik. Limfosit memiliki fungsi utama yaitu memproduksi antibodi sebagai respon terhadap benda asing yang difagositosis oleh makrofag (Tizard, 2000). Gambar monosit dan limfosit hasil apusan darah dapat dilihat pada Gambar 3.

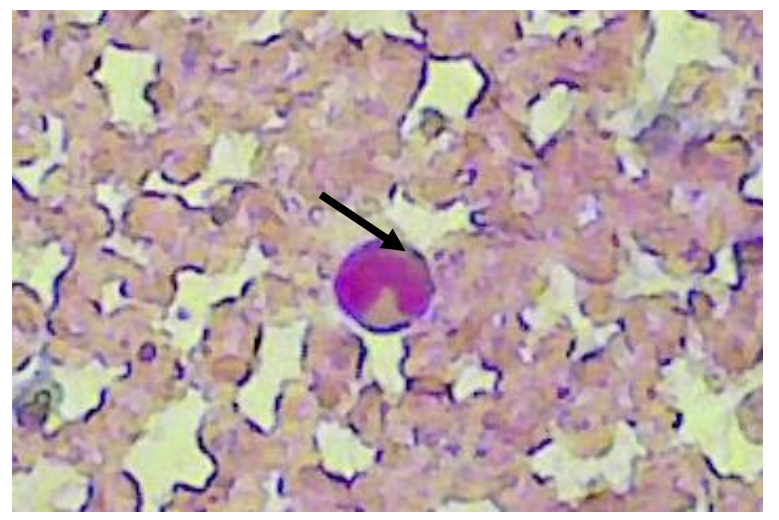

(a)

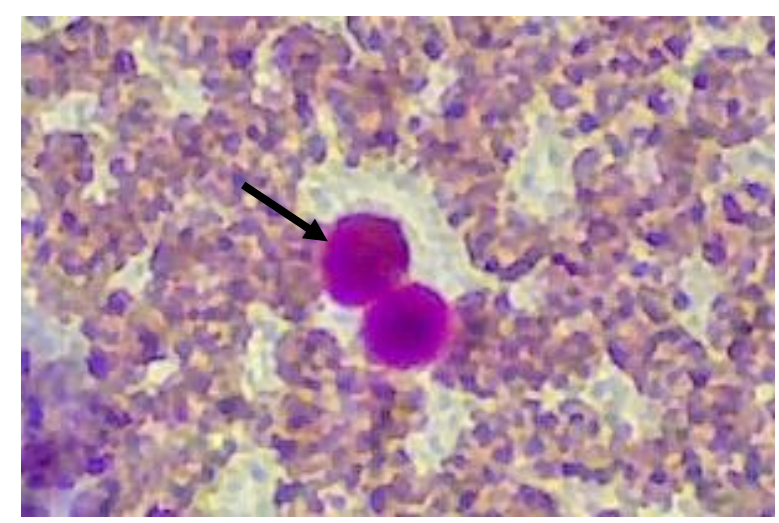

(b)

Gambar 3. Morfologi agranulosit (a) monosit dan (b) limfosit. Tanda panah menunjukkan jenis agranulosit menggunakan perbesaran 400x 


\section{PEMBAHASAN}

\section{Pengaruh paparan asap rokok elektrik terhadap kadar hemoglobin dan rata-rata jumlah eritrosit mencit}

Penelitian ini memperlihatkan hasil bahwa paparan asap rokok dengan volume cairan yang berbeda mengakibatkan terjadinya peningkatan kadar hemoglobin dan rata-rata jumlah eritrosit dibandingkan dengan kontrol. Hal ini diduga akibat adanya karbon monoksida (CO) yang terkandung dalam rokok elektrik. Hemoglobin yang berada di dalam eritrosit merupakan protein tetrametrik yang mampu berikatan dengan oksigen dan melepaskan oksigen tersebut ke dalam jaringan. Hemoglobin juga dapat mengikat karbon dioksida dan mengembalikannya ke jaringan untuk dikeluarkan ke paru (Granner et al., 2009). Kadar hemoglobin dalam darah dapat terganggu apabila terdapat zat toksik ataupun radikal bebas yang masuk, salah satunya CO. Karbon monoksida merupakan salah satu senyawa radikal bebas yang ada di dalam rokok elektrik (Casebolt et al., 2019) yang apabila terhirup akan bercampur dalam darah dan berikatan dengan hemoglobin. Afinitas hemoglobin dengan CO lebih kuat 245 kali dibandingkan afinitas hemoglobin dengan oksigen (Dewanti, 2018). Ikatan antara hemoglobin dan CO akan membentuk karboksihemoglobin, suatu inaktif hemoglobin. Semakin banyak CO yang masuk, jumlah karboksihemoglobin akan semakin meningkat. Hal ini mengakibatkan ikatan hemoglobin dengan oksigen menurun sehingga berpengaruh terhadap terganggunya transportasi oksigen pada jaringan yang lain. Kurangnya pasokan oksigen dalam jaringan dapat menyebabkan terjadinya hipoksia (Leifert, 2008).

Upaya untuk mengatasi berkurangnya kadar oksigen dalam jaringan adalah dengan membentuk hemoglobin baru. Kurangnya kadar oksigen dalam jaringan, mengaktifkan hormon erythropoietin (Epo) dalam ginjal sebagai bentuk adaptasi terhadap defisiensi oksigen (Restuti et al., 2018). Kadar oksigen yang rendah akan mengaktifkan ginjal untuk mensekresikan eritropoeitin (Epo) dalam jumlah besar menuju darah. Kadar Epo yang tinggi akan mengaktifkan pembentukan eritrosit dalam sumsum tulang melalui peningkatan survival, proliferasi dan diferensiasi progenitor eritroid (Sartika et al., 2008). Berdasarkan hal tersebut, maka pembentukan hemoglobin berkorelasi dengan jumlah eritrosit karena hemoglobin dibentuk dalam eritrosit. Peningkatan jumlah eritrosit akan meningkatkan kadar hemoglobin dalam darah.

Peningkatan rata-rata jumlah eritrosit yang signifikan dijumpai pada paparan asap rokok elektrik volume $4 \mathrm{ml}$ yang mengandung dosis 24 $\mathrm{mg}$ nikotin. Penggunaan dosis nikotin yang tinggi dalam penelitian ini berpengaruh terhadap ratarata jumlah eritrosit dalam darah. Penelitian Irawati et al. (2011) menyebutkan bahwa paparan asap rokok dengan dosis 15-30 mg nikotin pada manusia dapat meningkatkan viskositas darah. Viskositas darah dipengaruhi oleh hematokrit. Hematokrit terdiri atas eritrosit. Jumlah eritrosit yang meningkat menyebabkan meningkatnya hematokrit yang berdampak terhadap meningkatnya viskositas darah. Jumlah eritrosit pasca paparan asap rokok berkisar antara 9,08$9,56 \times 10^{6} / \mathrm{mm}^{3}$.Nilai tersebut masih dalam batas normal namun hampir melebihi kisaran normal tersebut. Jumlah eritrosit normal mencit berkisar

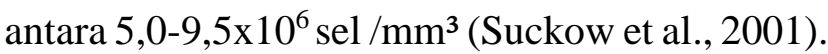

Rokok eletrik mengandung senyawa radikal bebas berupa gas $\mathrm{CO}$ yang dapat berikatan dengan hemoglobin dan dapat menurunkan kadar oksigen dalam jaringan (Casebolt et al., 2019). Semakin banyak $\mathrm{CO}$ yang masuk maka kadar hemoglobin dalam darah juga akan meningkat (Shah et al., 2012). Menurut Vakali et al. (2014) rokok elektrik dapat menyebabkan penurunan saturasi oksigen. Saturasi oksigen merupakan presentasi hemoglobin berikatan dengan oksigen. Saturasi oksigen yang menurun diakibatkan karena hemoglobin lebih banyak mengikat senyawa lain yakni CO yang terkandung dalam rokok elektrik (Sudaryanto, 2016). Peningkatan kadar hemoglobin merupakan bentuk adaptasi tubuh dalam mengatasi kekurangan oksigen yang diakibatkan oleh adanya gas $\mathrm{CO}$ yang masuk. Kadar hemoglobin pasca paparan asap rokok 
berkisar antara 16,01-16,28 $\mathrm{g} / \mathrm{dL}$ yang masih masuk dalam kategori normal. Kadar $\mathrm{Hb}$ tertinggi dijumpai pada perlakuan volume $4 \mathrm{ml}$ yaitu 16,28 g/dL. Kadar hemoglobin normal pada mencit berkisar antara 10,9-16,3 g/dL (Suckow et al., 2011). Paparan asap rokok yang semakin lama akan meningkatkan kadar hemoglobin dalam darah karena CO yang terhirup juga semakin banyak.

\section{Pengaruh paparan asap rokok elektrik terhadap jumlah leukosit dalam darah}

Rata-rata jumlah leukosit setelah paparan asap rokok lebih rendah dibandingkan dengan kontrol. Hal ini menunjukkan bahwa paparan asap rokok elektrik dapat menurunkan rata-rata jumlah leukosit dalam darah. Penurunan jumlah leukosit dipengaruhi oleh berkurangnya produksi leukosit, penurunan pelepasan leukosit dari sumsum tulang dan meningkatnya migrasi leukosit menuju organ atau jaringan yang terinfeksi. Kurangnya produksi leukosit dan menurunnya pelepasan leukosit dari sumsum tulang berkaitan dengan menurunnya aktifitas prekusor mieloid dalam sumsum tulang (Schmid et al., 2018). Prekusor mieloid merupakan prekusor yang membentuk leukosit jenis monosit dan granulosit yang terdiri atas neutrofil, basofil dan eosinofil. Menurut Serobyan et al. (2005) nikotin dapat mengganggu aktivitas hemopoitik yang ditandai dengan menurunnya aktivitas prekusor mieloid dan prekusor limfoid di dalam sumsum tulang yang menyebabkan berkurangnya leukosit matang untuk pertahanan. Turunnya aktivitas prekusor limfoid dapat menyebabkan produksi limfosit menurun. Penelitian terkait menunjukkan bahwa paparan asap rokok elektrik terhadap Rana pipiens dengan dosis nikotin $6 \mathrm{mg}, 12 \mathrm{mg}, 18 \mathrm{mg}$, dan $24 \mathrm{mg}$ selama 3 minggu dapat menurunkan jumlah limfosit dalam darah (Jude et al., 2017).

Prekusor mieloid atau disebut mieloblast akan membentuk leukosit melalui dua tahapan yaitu mitosis dan maturasi. Tahapan ini terjadi dalam sumsum tulang. Pada tahapan mitosis mieloblast membelah sebanyak empat kali menjadi promielosit, selanjutnya promielosit akan membelah kembali menjadi mielosit. Tahapan selanjutnya yaitu maturasi yang terdiri atas diferensiasi metamielosit menjadi sel batang, selanjutnya sel batang akan berdiferensiasi menjadi granulosit matang. Granulosit matang tidak akan dilepaskan langsung menuju jaringan tetapi ditimbun di dalam sumsum tulang hingga diperlukan (Mescher, 2017). Paparan asap rokok elektrik akan mengganggu tahapan mitosis dan pematangan mieloblast menyebabkan berkurangnya granulosit matang yang terbentuk sehingga berpengaruh pada berkurangnya jumlah leukosit. Menurut Chapman et al. (2019) paparan rokok elektrik $12 \mathrm{mg}$ nikotin selama 3 minggu dapat menurunkan jumlah leukosit $M$. musculus.

Rata-rata jumlah leukosit kelompok perlakuan perlakuan paparan asap rokok elektrik dengan volume cairan $1 \mathrm{ml}$ tidak berbeda nyata dengan rata-rata kelompok perlakuan paparan asap rokok elektrik dengan volume cairan $2 \mathrm{ml}$ dan $4 \mathrm{ml}$. Jumlah leukosit pasca paparan asap rokok berkisar antara 3,20-3,51 x10\%3/ 1 . Meskipun masih dalm kisaran normal, nilai tersebut hampir melewati kisaran normal. Jumlah leukosit normal berkisar antara 3-14,2 x 103/ $\mu$ l (Suckow et al., 2001). Pada kelompok perlakuan rata-rata jumlah leukosit tertinggi ditemukan pada kelompok perlakuan paparan asap rokok elektrik dengan volume cairan $4 \mathrm{ml}$ yang mengandung $24 \mathrm{mg}$ nikotin. Hal ini menunjukkan bahwa paparan asap rokok elektrik dengan kadar nikotin yang tinggi dapat meningkatkan jumlah leukosit. Hal tersebut didukung oleh penelitian Jude et al. (2017) yang menunjukkan bahwa paparan asap rokok elektrik dengan kadar nikotin $24 \mathrm{mg}$ selama 3 minggu pada Rana pipiens dapat meningkatkan jumlah leukosit. Peningkatan jumlah leukosit merupakan reaksi yang dilakukan sebagai bentuk proteksi terhadap zat asing berupa nikotin yang masuk dalam tubuh.

\section{Pengaruh paparan asap rokok elektrik terhadap jenis-jenis leukosit}

Rata-rata jumlah limfosit setelah paparan asap rokok memiliki jumlah yang lebih rendah dibandingan dengan kontrol. Hal ini menunjukkan bahwa paparan asap rokok elektrik dapat menurunkan rata-rata jumlah limfosit 
dalam darah. Menurut Jude et al. (2017) paparan asap rokok elektrik dengan dosis nikotin $6 \mathrm{mg}$, $12 \mathrm{mg}, 18 \mathrm{mg}$, dan $24 \mathrm{mg}$ selama 3 minggu pada Rana pipiens dapat menurunkan rata-rata jumlah limfosit dalam darah. Paparan asap rokok elektrik dapat menyebabkan terjadinya stress terhadap mencit. Keadaan stress tersebut dapat menurunkan rata-rata jumlah limfosit dalam darah (Fatmah, 2006). Stres menstimulasi sekresi corticotrophin releasing factor (CRF) dari hipotalamus menuju kelenjar pituitari. Sekresi CRF merangsang pelepasan adenocorticotrophin hormone (ACTH) oleh kelenjar pituitary yang selanjutnya akan merangsang korteks adrenal untuk melepaskan hormone glukokortikoid terutama kortisol (Lisdiana, 2012). Pelepasan glukokortikoid dalam jumlah tinggi akan menekan respon imun, membunuh limfosit, involusi jaringan limfoid (Lukman, 2008). Disamping itu, glukokortikoid juga menyebabkan delesi limfosit melalui mekanisme apoptosis. Mekanisme apoptosis dapat dilihat pada Gambar 4.

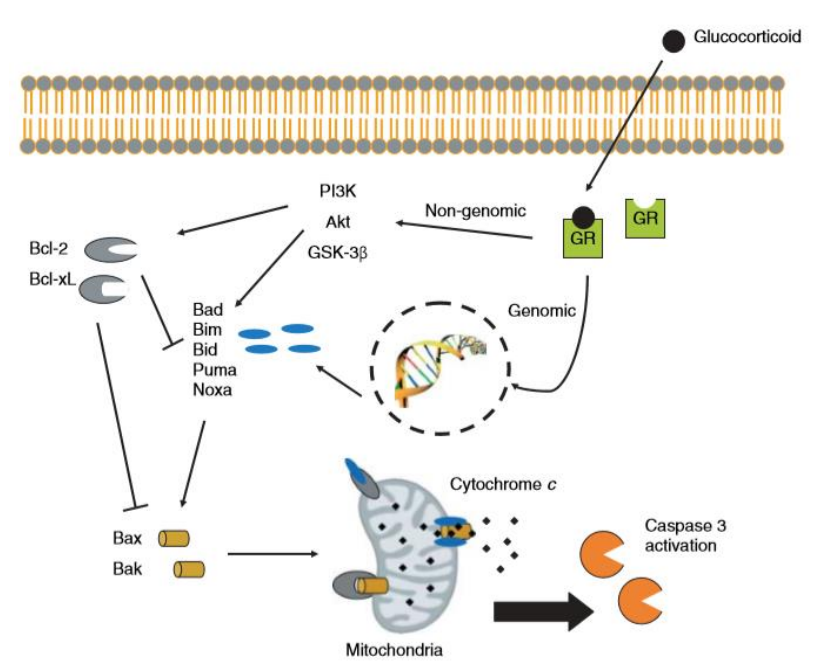

Gambar 4. Mekanisme apoptosis yang disebabkan oleh hormon glukokortikoid (Schlossmacher et al., 2011).

Mekanisme apoptosis diawali dengan menempelnya reseptor glukokortikoid pada ligan yang menyebabkan reseptor tersebut aktif. Peristiwa pengaktifan reseptor oleh ligan melibatkan beberapa senyawa protein melalui proses cascade sehingga sel mengalami apoptosis. Reseptor yang berikatan dengan ligan akan menempuh dua jalur yakni jalur genomik dan jalur non-genomik. Apoptosis sel limfosit cenderung menempuh jalur genomik dibandingkan jalur nongenomik. Hal ini disebabkan karena pada jalur nongenomik terdapat protein $\mathrm{Bcl}-2$ dan $\mathrm{Bcl}-\mathrm{XL}$ yang merupakan senyawa anti apotosis yang dalam keadaan tertentu akan menghambat kerja protein pro apoptosis. Jalur genomik merangsang gen dalam sel untuk memproduksi pro apoptosis yang kemudian akan beraksi dalam membran mitokondria. Sitokrom akan keluar dari mitokondria dan mengaktivasi enzim caspase yang menginduksi apoptosis. Peristiwa apoptosis berpengaruh terhadap menurunnya rata-rata jumlah limfosit dalam darah (Schlossmacher et al., 2011).

Berbeda halnya dengan limfosit, paparan asap rokok tidak berpengaruh terhadap jumlah granulosit dan MID. Granulosit terdiri atas neutrofil sedangkan MID terdiri atas basofil, eosinofil dan monosit. Berdasarkan data hasil yang diperoleh tampak bahwa paparan asap rokok elektrik tidak berpengaruh terhadap jumlah granulosit dan jumlah MID. Hal ini didukung oleh penelitian Badea et al. (2019) yang menunjukkan bahwa penggunaan rokok elektrik heets lebih dari 15 heets/hari tidak berpengaruh terhadap jumlah neutrofil. Penelitian lain juga menyebutkan bahwa menunjukkan bahwa paparan asap rokok yang mengandung $6 \mathrm{mg}, 12 \mathrm{mg}$ dan $24 \mathrm{mg}$ nikotin selama 3 minggu tidak berpengaruh terhadap jumlah monosit, eosinofil dan basofil Rana pipiens (Jude et al., 2017). Rata rata jumlah granulosit mencit pada penelitian ini berkisar antara $0,04-0,10 \times 10^{3} / \mu 1$ dan rata-rata jumlah MID berkisar antara $0,05-0,07 \times 10^{3} / \mu 1$. Jumlah granulosit dan MID yang diperoleh pada penelitian ini masih berada pada kisaran normal. Jumlah rata-rata neutrofil berkisar antara 0,46$2,20 \times 10^{3} / \mu 1$ dan jumlah rata-rata MID berkisar antara $0,00-1,43 \times 10^{3} / \mu 1$ (Suckow et al., 2001).

\section{SIMPULAN}

Berdasarkan penelitian yang telah dilakukan, paparan asap rokok elektrik dengan volume cairan $1 \mathrm{~mL}$ berpengaruh terhadap profil 
hematologi mencit dengan meningkatkan kadar $\mathrm{Hb}$, menurunkan jumlah leukosit dan limfosit. Paparan dengan volume $4 \mathrm{~mL}$ meningkatkan ratarata jumlah eritrosit. Perlakuan dengan volume cairan yang berbeda tidak berpengaruh terhadap rata-rata jumlah granulosit dan MID mencit jantan (M. musculus L.).

\section{KEPUSTAKAAN}

Ardina R dan Rosalinda S. 2018. Morfologi eosinofil pada apusan darah tepi menggunakan pewarnaan giemsa, wright, dan kombinasi wright-giemsa. Jurnal Surya Medika. 3(2): 5-12.

Badea M, Gaman L, Delia C, Ilea A, Leasu F, Hernández LAH, Luzardo OP, Rădoi M, Rogozea L. 2019. Trends of lipophilic, antioxidant and hematological parameters associated with conventional and electronic smoking habits in middLe-ageromanians. $J$. Clin. Med. 8(665): 1-21.

Campagna D, Cibella F, Caponnetto P, Amaradio MD, Caruso M, Morjaria JB, dan Polosa R. 2016. Changes in breathomics from a 1-year randomized smoking cessation trial of electronic cigarettes. European Journal of Clinical Investigation. 46(8): 698-706.

Casebolt R, Cook SJ, Islas A, Brown A, Castle K, Dutcher DD. 2019. Carbon monoxide concentration in mainstream e-cigarette emissions measured with diode laser spectroscopy. Tob Kontrol. 0: 1-4.

Chapman DG, Casey DT, Ather JL, Aliyeva M, Daphtary N, Lahue KG, Velden JLVLV, Heininger YMWJ, Irvin CG. 2019. The effect of flavoured ecigarettes on murine allergic airways disease. Scientific Report. 9: 13671 .

Colville T, Bassert JM. 2008. Clinical Anatomy and Physiology for Veterinary Technician. Missouri: Elsevier.

Dewanti IR. 2018. Identifikasi paparan CO, kebiasaan, dan kadar $\mathrm{COHb}$ dalam darah serta keluhan kesehatan di basement apartemen waterplace Surabaya. Jurnal Kesehatan Lingkungan. 10(1): 59-69.
Edmonds PJ, Copeland C, Conger A, Richmond BW. 2020. Vaping-induced diffuse alveolar hemorrhage. Respiratory Medicine Case Report. 29: 1-3.

Fatmah. 2006. Respon imunitas yang rendah pada tubuh manusia usia lanjut. Makara Kesehatan. 10(1): 47-53.

Frandson RD 1992. Anatomi dan Fisiologi Ternak. Edise ke-4. Terjemahan: B. Srigandono dan Koen Praseno. Yogyakarta: Gajah Mada University Press.

Garcia-Arcos I, Geraghty P, Baumlin N, Campos M, Dabo AJ, Jundi B, Foronjy R. 2016. Chronic electronic cigarette exposure in mice induces features of copd in a nicotine-dependent manner. Thorax. 71(12): 1119-1129.

Granner MK, Murray RR, Rodwell VW. 2009. Biokimia Harper. Jakarta: EGC.

Handayani L, Irianti N, Yuwono E. 2013. Pengaruh pemberian minyak ikan lemuru terhadap kadar eritrosit dan trombosit pada ayam kampung. Jurnal Ilmiah Peternakan. 1(1): 39-46.

Irawati L, Julizar, Irahmah M. 2011. Hubungan jumlah dan lamanya merokok dengan viskositas darah. Majalah Kedokteran Andalas. 35(2): 137-146.

Jude AJ, Krishna S. 2017. Effect of e-liquid from an electronic cigarette on the immune profil of Rana pipiens. Bios. 88(4): 162-168.

Junqueira LC, Carneiro J. 2004. Histologi Dasar: Teks dan Atlas Edisi Kesepuluh. Jakarta: EGC.

Leifert JA. 2008. Anemia and cigarette smoking. Int J Lab Hematol. 30: 84-177.

Lisdiana. 2012. Regulasi kortisol pada kondisi stress dan addiction. Biosantifika. 4(1): 1926.

Lukman A. 2008. Mekanisme dan regulasi hormon glukokortikoid pada manusia. Jurnal Program Studi Pendidikan Biologi Universitas Jambi. 1(1): 25-28.

Makawekes TM, Kalangi SJR, Taufiq FP. 2016. Perbandingan kadar hemoglobin darah pada 
pria perokok dan bukan perokok. Jurnal eBiomedik (eBm). 4(1).

McConnell R, Barrington-Trimis JL, Wang K, Urman R, Hong $\mathrm{H}$, Unger J dan Berhane $\mathrm{K}$. 2017. Electronic cigarette use and respiratory symptoms in adolescents. American Journal of Respiratory and Critical Care Medicine. 195(8): 1043-1049.

Mescher AL. 2017. Junqueira's Basic Histology: Text and Atlas, $14^{\text {th }} \mathrm{Ed}$. United States: The McGraw-Hill Company, Inc. Terjemahan oleh Tambayong, Jan. 2017. Jakarta: EGC Press.

Nursidika P, Permana EV, Sustrianti. 2019. Perubahan jumlah dan jenis leukosit pada pengguna rokok elektrik. Meditory. 7(2) : 94101.

Rahardjo T, Nurhayati S, Darlina. 2011. Pengamatan hematologi pada mencit pasca infeksi plasmodium berghei iradiasi gamma stadium eritrositik. Seminar Nasional Keselamatan Kesehatan dan Lingkungan 7: 107-118.

Restuti ANS, Suryana AL. 2018. Asupan protein dan parameter hematologi pada perokok. $J K V$. 4(2): 77-90.

Sartika IN, Retasa W, Kardana M, Mudita ID.2008. Peran eritropoetin pada anemia prematuritas. Sari ediatri. 9(6): 375-379.

Schlossmacher G, Steven A, White A. 2011. Glucocorticoid receptor-mediated apoptosis: mechanisms of resistance in cancer cells. Journal of Endocrinology. 211: 17-25.

Schmid JMP, Kuehni CE, Strippoli MPF, Roiha HL, Pavlovic R, Latzin P, Gallati S, Khaemer R, Dahinden C, Frey U. 2007. Maternal tobacco smoking and decreased leucocytes, including dendritic cells, in neonates. Pediatric Research. 61(4): 462-466.

Serobyan N, Orlovskaya I, Kozlov V, Khaldoyanidi SK. 2005. Exposure to nicotine during gestation interferes with the colonization of fetal bone marrow by hematopoietic stem/progenitor cell. Stem cell and Development. 14: 81-91.
Shah BK, Nepal AK, Agrawal M, Sinha AK. 2012. The effect of cigarette smoking on hemoglobin levels compared between smokers and non smokers. Sunsari Technical College Journal. 1(1): 42-44.

Shi H, Fan X, Horton A, Haller ST, Kennedy DJ, Schiefer IT, Dworkin L, Cooper CJ, Tian J. 2019. The effect of electronic-cigarette vaping on cardiac function and angiogenesis in mice. Scientific Reports. 9(4085) : 1-9.

Steel RGD, Torrie JH. 1993. Prinsip dan Prosedur Statistika (Pendekatan Biometrik) Penerjemah B. Sumantri. Jakarta: Gramedia Pustaka Utama.

Suckow MA, Danneman P, Brayton C. 2001. The Laboratory Mouse (A Volume In The Laboratory Animal Pocket Reference Series. New York: CBR Press.

Sudaryanto WT. 2016. Hubungan antara derajat merokok aktif, ringan, sedang dan berat dengan kadar saturasi oksigen dalam darah $\left(\mathrm{SpO}_{2}\right)$. Jurnal Terpadu Ilmu Kesehatan. 6(1): 01-117.

Tizard IR. 2000. Imunology: An Introduction. $6^{\text {th }}$ $E d$. New York: Saunders College Publishing.

Vardavas CI, Anagnostopoulos AN, Kougias M, Evangelopoulou V, Connolly GN, Behrakis PK. 2012. Short-term pulmonary effects of using an electronic cigarette. Chest. 141(6): 1400-1406.

Vakali S, Tsikrika S, Gennimata SA, Kaltsakas G, Palamidas A, Kouloris N, Gratziou C. 2014. E-cigarette acute effect on symptoms and airway inflammation: comparison of nicotine with a non cigarette. Tobacco Induced Diseas. 12(1): 35 .

Weiss DJ, Wardrop KJ. 2010. Veterinary Hematology $9^{\text {th }} E d$. USA: John Willey and Sons Ltd.

Wibowo DV, Pangemanan DHC, Hedison P. 2017. Hubungan merokok dengan kadar hemoglobin dan trombosit pada perokok dewasa. Jurnal e-Biomedik (eBm). 5(2).

Widyastuti DA. 2013. Profil darah tikus putih wistar pada kondisi subkronis pemberian natrium nitrit. $J S$. 31(2): 201-215. 